\title{
THE DISCOURSE SEMANTICS OF ATTITUDINAL RELATIONS: CONTINUING THE STUDY OF LEXIS
}

\author{
J R Martin \\ Martin Centre for Appliable Linguistics \\ Shanghai Jiaotong University \\ 800 Dongchuan Road, 200240 Shanghai, China \\ University of Sydney \\ The University of Sydney NSW 2006, Australia
}

\begin{abstract}
This paper explores some aspects of the problem of categorizing attitudinal relations in English, as part of a description of evaluation informed by systemic functional linguistics (SFL) - APPRAISAL. It reviews paradigmatic and syntagmatic orientations to lexis within this tradition, and the development of typological and topological representations of systemic relations. Corpus based argumentation is considered in relation to work on evaluation by Bednarek 2008; and proposals for continuing the study of lexis are suggested, focusing on resources for negotiating sadness and negative reactions to behavior (e.g. embarrassed, ashamed) and the affordances of topological representation. The paper highlights the possibilities and challenges involved in continuing the study of lexis in descriptions using SFL as their informing theory.
\end{abstract}

Keywords: Appraisal, attitude, affect, topology, lexis, discourse semantics

\section{THEORY AND DESCRIPTION}

In late 2012 I was approached by a very concerned research student who reported that some people were saying 'Appraisal Theory' wasn't a theory at all, but just a description. To which I replied: "Yes, of course. That's right. Systemic Functional Linguistics (hereafter SFL) is the theory. APPRAISAL is a description of resources for evaluation in English".

A comparable confusion around the relation of theory to description arises in the introduction to a recent collection of papers on language education informed by SFL (Whittaker et al. 2009: 2): "While SFL recognised an 'interpersonal' component of meaning, the model as stated did not readily support the analysis of speaker attitudes in text. During the 1990s, Peter White, Jim Martin and others developed an approach to attitudinal analysis, complementary to SFL, called 'Appraisal Theory"'. Chapter 1 of Martin \& White's The Language of Evaluation on the other hand is quite explicit that its "model of evaluation evolved within the general theoretical model of SFL" (2005: 7) and introduces appraisal resources in relation to relevant dimensions of SFL theory, including metafunction, realization, axis, system, structure, instantiation, genesis, register and genre. It concludes by situating "appraisal as an interpersonal system at the level of discourse semantics" (2005: 33). To my mind, the relation of theory to description 
is made clear. That said, colleagues working with APPRAISAL, and I include myself among them, have made countless references to 'Appraisal Theory' in presentations and publications, as a short-hand for a 'description of APPRAISAL resources in English within the general theoretical framework of SFL'. We need to be more careful.

The confusion at play here is of course between theory and description, or what Bernstein (2000: 131 - 141) refers to as L1 (the internal language of description) and L2 (the external language of description). As Maton 2014: 127 explains (elaborating Bernstein's (2000: 132) definitions): "L1 'refers to the syntax whereby a conceptual language is created' or how constituent concepts of a theory are interrelated; and L2 'refers to the syntax whereby the internal language can describe something other than itself' or how a theory's concepts are related to referents". In these terms SFL is the L1 informing APPRAISAL, which is the L2. As Matthiessen \& Nesbitt 1996 clarify, there is no such thing as a theory neutral description. Descriptions which purport to be theory neutral are simply assuming a naturalized taken for granted theorisation, much as citizens who claim to be free of ideology enact a naturalized hegemony in which only those trying to redistribute power are viewed as political. I won't pursue the discussion of internal and external language of description here; for elaboration see Muller 2007 on verticality and grammaticality, and Maton 2014 (especially his discussion of specialization, semantic gravity and semantic density). But the distinction between what linguists think of as theory and as description is crucial, and one aspect of the relation between L1 and L2 as far as the categorization of attitudinal relations is concerned is the main focus of this paper.

\section{SFL AS A RELATIONAL THEORY OF MEANING}

As is well known, SFL has evolved as a theory of language foregrounding paradigmatic relations as the basic organizing principle of both theory and description. Formalisation of these relations on the basis of the structures through which they are realized gives rise to crucial derived concepts such as rank, metafunction and stratification which function as comments on the bundling of paradigmatic relations in the organisation of language. As such, the theory builds on Saussure's understanding of the sign and valeur, Hjelmslev's interpretation of language as a stratified system of signs and Firth's notion of meaning as function in context. For a basic introduction to these ideas see Matthiessen \& Halliday 2009 and Martin 2013. The critical concept arising from this intellectual history is the idea that language is a network of relations, an orientation shared with what was originally known as stratificational linguistics (Lamb 1996, Lockwood 1972), which has a comparable theoretical heritage. As far as meaning is concerned, this gives rise to a relational theory of meaning in which meaning is formalized as networks of options. In an L1 of this kind, language is conceived as a resource, and meaning as choice. Asking what a choice means involves explicitly relating that choice to other options in relevant systems (on a higher or lower rank, on a higher or lower stratum, and in one or another metafunction). 
It is important to contrast this relational theory of meaning with the common sense referential one that is often taken as the basis for alternative conceptualisations in linguistics, philosophy and psychology. In common sense terms it makes sense to ask what a word means, and answer by pointing to some concrete object it refers to, or, where this is not possible, to offer a definition (the dictionary strategy). In this approach, words for example are conceived as having meaning (as realizing or encoding meaning if we want to say this more formally). From a relational perspective on the other hand, words don't have meaning; rather they do meaning — they mean in relation to the other words that might have been chosen. Similarly groups and phrases mean in relation to other groups and phrases, clauses in relation to other clauses, exchanges in conversation in relation to other exchanges, phases of discourse is relation to other phases, genres in relation to other genres and so on. So the task of description in a relational model of language is to relate choices to one another, as explicitly as possible (as opposed to offering definitions or relating meanings to real world entities or cognitive concepts). As far as APPRAISAL resources are concerned, this means describing how evaluative meanings are related to one another. And if we are focusing on feelings (i.e. ATTITUDE), as we are in this paper, this means building up a picture of the feelings we mean, describing how they are related to one another (looking round), specifying how they are realized (looking down) and outlining what they realize (looking up).

Note in practical terms that a relational theory of meaning implies that a good thesaurus is going to be a much more valuable resource than a dictionary. On the whole, definitions in dictionaries are not very well coordinated with one another, since dictionary makers tend to work a word at a time rather than with sets of related meanings. It also implies that consulting a translator will be far more insightful than introspecting about the meaning of an attitudinal expression. This is because most of us are not very good at bringing the relational meaning of a feeling expression to consciousness, whereas translators spend their whole life worrying relationally about the meaning of a word in one language and its relation to alternative translations in another. Their relational perspective is an invaluable resource in this regard (cf. de Souza 2010 on translating evaluative language from English into Portuguese). The basic message I am trying to get across here is that a relational perspective on meaning means that we need to think relationally. Formally speaking, this means looking closely at how paradigmatic relations are modeling typologically and topologically as far as the discourse semantics of APPRAISAL is concerned.

\section{TYPOLOGY AND TOPOLOGY}

SFL's usual strategy for formalizing paradigmatic relations is a system network. A system network is a two-dimensional static display of logical relations among choices for meaning. In Fig. 1 below, the kind of traffic light system used in Hjelmslev 1947 to illustrate Saussure's concepts of the sign and valeur is formalized in SFL terms as a system network with three options (technically features). The basic meaning of each choice is its relation to other choices (its valeur). Since this is a very simple semiotic system, there is not much to say from round about, above or below, since choices do 
not bundle into metafunctions, ranks or strata. Out of respect for Saussure's concept of the sign I have used a yin/yang symbol to represent each option, and double-labeled each sign with respect to its fusion of signifie and signifiant (stop/red, speed up/yellow and go/green). The arrow and square bracket organize the signs as alternatives; in this system you have to choose one of the three options (not none and not more than one).

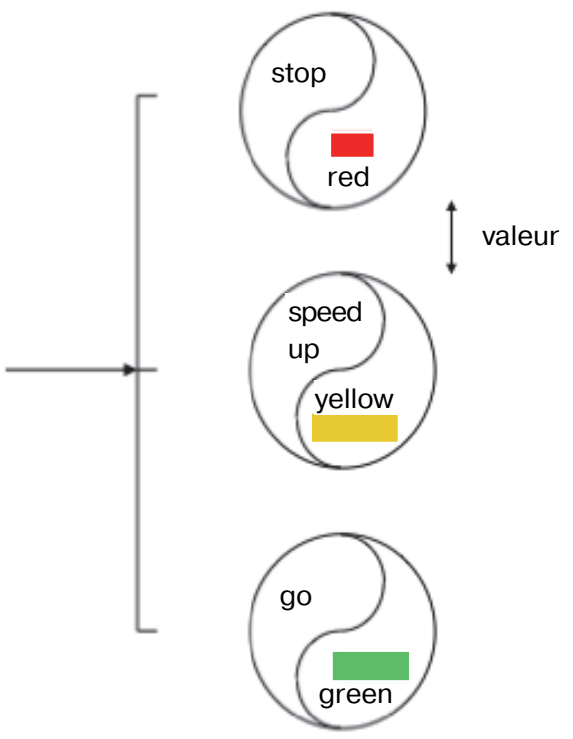

Fig. 1: Traffic light typology (after Saussure and Hjlemslev)

System networks also afford the possibility of cross-classification as in Fig. 2 below. In this abstract network, the choice of $[\mathrm{a}]^{1}$ or $[\mathrm{b}]$ is simultaneous with the choice of [c] or $[\mathrm{d}]$, and so $[\mathrm{a} / \mathrm{c}],[\mathrm{a} / \mathrm{d}],[\mathrm{b} / \mathrm{c}]$ and $[\mathrm{b} / \mathrm{d}]$ are all possible combinations of meanings. Where two systems are involved the relations involved can be easily displayed as a paradigm - a two-dimensional static display table with rows (for one system) and columns (for the other). The boxes in the table can then be used to show how features are realized. Tables of this kind are often used in language teaching materials for languages with portmanteau morphemes (i.e. morphemes realizing more than one system, such as verb inflections in Romance languages - which may realise TENSE and MOOD, PERSON and NUMBER). Syntagms typically realize more than one system, and so paradigms are commonly used in SFL to display the realisations of simultaneous group, phrase, clause, clause complex, exchange or genre systems. The limitation of paradigms is that they effectively display the interaction of two simultaneous systems but a third dimension (involving reformulation as an imaginary cube) makes them difficult to view ${ }^{2}$; and

${ }^{1}$ I follow here the standard SFL convention of enclosing features in square brackets (for this and related conventions see Martin 2013).

2 Consider in this regard the front over of the third edition of Halliday \& Matthiessen's Introduction to Functional Grammar (2004) where three dimensions are deployed (for strata, metafunction and instantiation) and a fourth dimension (rank) has been pulled out as a parallel image. 
a fourth dimension strains the visual affordances of a two-dimensional page or screen. System networks on the other hand can cross-classify any number of systems using the curly bracket (the brace) — which specifies the $[\mathrm{a} / \mathrm{b}]$ system as simultaneous with the $[\mathrm{c} / \mathrm{d}]$ system in Fig. 2.
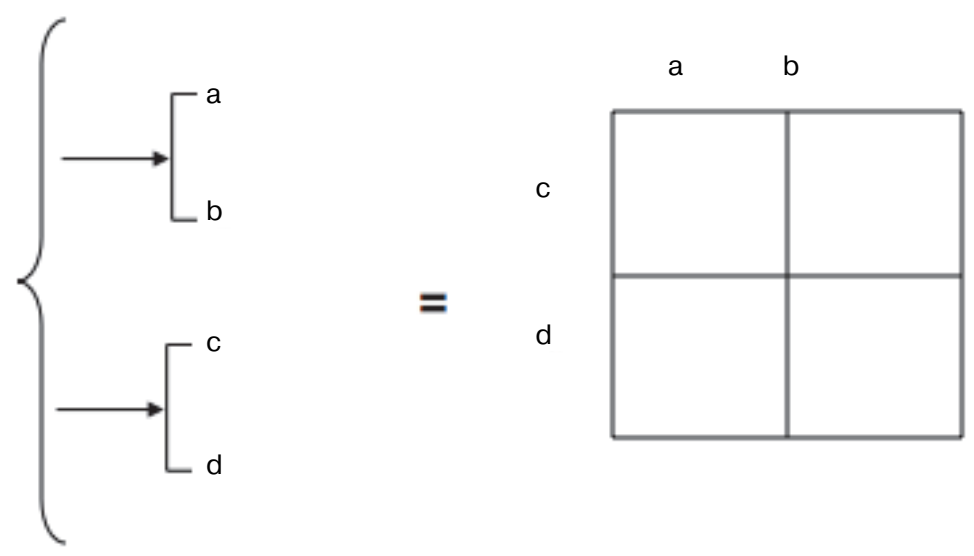

Fig. 2: Cross-classification in relation to a paradigm

Turning to the relation of typology to topology as far as modeling paradigmatic relations is concerned we need to introduce the notion of clined systems. Clined systems scale meanings from one pole to another. There is no standard representation for this kind of system in SFL; in Fig. 3 I have tilted the systems clock-wise to signal that they involve a cline rather than a categorical opposition between features [a] and [b] and between features [c] and [d]. Where two systems are involved, this kind of network can be re-expressed as a topology - with one clined system taken as the vertical axis and the another clined system as the horizontal one. This creates a space in which meanings can be graded as more or less [a] or [b] and more or less [c] or [d]. Theoretically speaking a topology is not limited to two dimensions; but practically speaking (as with paradigms) a third dimension is challenging as far as viewing is concerned, and additional dimensions require considerable ingenuity to display. The advantage of the topological perspective is that meanings can be graded in relation to one another instead of categorically opposed.

Interpersonal meanings in particular ${ }^{3}$ (e.g. Halliday's account of the semantics of MODALITY in English in Chapter 10 of Halliday \& Matthiessen 2014) lend themselves to description of this kind. For further discussion of the complementarity of modeling paradigmatic relations as typology and topology in SFL see Martin \& Matthiessen 1991. As indicated in Fig. 3, the regions construed in a topological display can be further interpreted as having their own centre/margin structure, with the centre deployed for ideal types (e.g. prototypical [a/c] below) and the margins for the less ideal (e.g. extreme [a] or almost [b] or extreme [c] or almost [d] below).

${ }^{3}$ Compare however the PROCESS TYPE topology on the front cover of the second edition of Halliday \& Matthiessen's Introduction to Functional Grammar (1994) or Martin \& Rose's 2008 topologies for register and genre. 


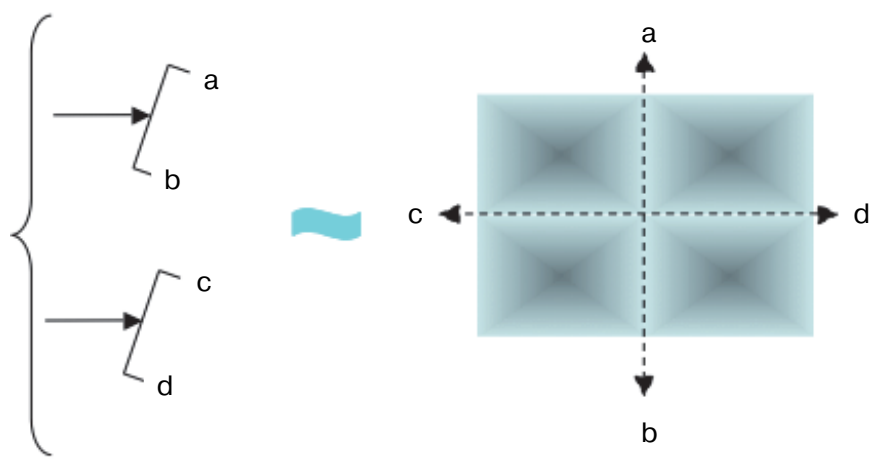

Fig. 3: Simultaneous clined systems in relation to topology

The complementarity of typology and topology will be familiar to linguists from their introductory courses in phonetics and phonology, where vowel systems tend to be presented typologically in terms of ideal types, and their phonetic realisations topologically in relation to tongue position. For Australian and New Zealand English, which have the same vowel system phonemically speaking, a topological diagram such as that in Fig. 4 might be used to show how New Zealand short vowels are spoken higher and further back than Australian ones (so that an Australian might hear New Zealand /sæks/ as /seks/, New Zealand /seks/ as /siks/ and New Zealand/siks/ as /suks/ and so on and delight in such misunderstandings).

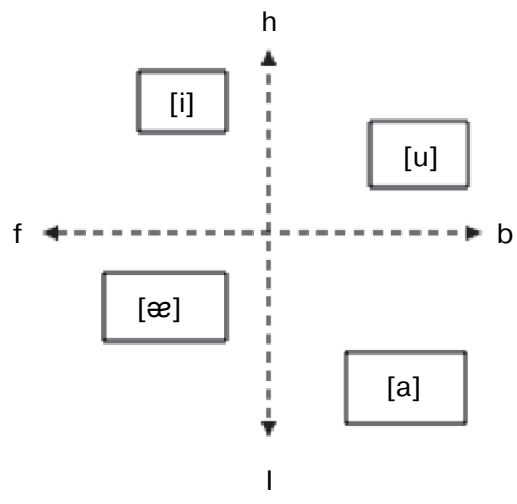

Fig. 4: A topological display for vowel articulations

For an exemplary exploration of the complementarity of typology and topology in relation to APPRAISAL see Bednarek 2007. Below I will review the two modeling strategies in relation to English ATTITUDE, in particular AFFECT, as presented in Martin \& White 2005; Bednarek 2007 discusses typology and topology across a fuller range of ATTITUDE systems.

\section{BEGINNING THE STUDY OF LEXIS}

For Halliday's teacher Firth, "The first principle of phonological and grammatical analysis is to distinguish between structure and system" (1957/1968: 186). As far as the structure of lexis is concerned Firth emphasized the importance of studying mutual ex- 
pectancies between words as texts unfold, which expectancies he referred to as collocation. This corpus perspective on lexis was developed by Sinclair and his colleagues at Birmingham, beginning with his seminal 1966 paper 'Beginning the study of lexis'. Hunston 2011 presents an overview of the contributions of this work to our understanding of evaluative language, including critical contributions by Bednarek $(2006,2008)$. The complementary lexis as system perspective was developed by Halliday $(1961,1966)$, in relation to his proposal that the "grammarian's dream is (and must be, such is the nature of grammar) of constant territorial expansion. He would like to turn the whole of linguistic form into grammar, hoping to show that lexis can be defined as "most delicate grammar"' (1961: 267). This proposal was insightfully explored by Hasan $1987^{4}$ in relation to a small set of material processes (gather, collect, accumulate; scatter, divide, distribute; strew, spill, share). Her typology takes material processes of disposal and their interaction with benefaction as a starting point and pushes the description in delicacy until the realization of choices can be specified in terms of specific disposal lexis.

I'll use an interpersonal example here to illustrate this conception of lexis as delicate grammar - drawing on Halliday \& Matthiessen's classification of Comment Adjuncts (2014: 190-193). Their first distinction is between what they call propositional and speech-functional comment (I use the features [feeling] vs [dialogism] for this in order to orient the discussion towards work on the appraisal system ENGAGEMENT). The more attitudinal comments only appear in statements (group 1 below), whereas the dialogic ones position a speaker's voice in statements and invite the addressee to position hers in questions (group 2 below).

Fortunately, we won the match.

*Fortunately, did we win the match?

*Fortunately, win the match.

Honestly, they won the match.

Honestly, did they win the match?

*Honestly, win the match.

Halliday \& Matthiessen then break the dialogic comments down into a what they call a qualified and an unqualified comment; the criteria they use for this distinction is the ability of the qualified type to be followed by the word speaking: e.g. generally speaking, frankly speaking, strictly speaking (cf. *admittedly speaking, *actually speaking).

Honestly speaking, I doubt they'll win.

Strictly speaking, it's invoking not inscribing feeling.

Admittedly, they won.

*Admittedly speaking, they won.

Actually, it's invoking.

*Actually speaking, it's invoking.

${ }^{4}$ For a book length exploration of lexis as delicate grammar, see Tucker 1998 on the lexicogrammar of adjectives. 
The qualified type is subsequently split, without explanation, into validity (generally, broadly, roughly etc.) and personal engagement subtypes. The distinctions introduced to this point are formalized as a system network below (which has as its unspecified point of origin the feature [indicative] in the system MOOD - since imperative clauses cannot be commented on).

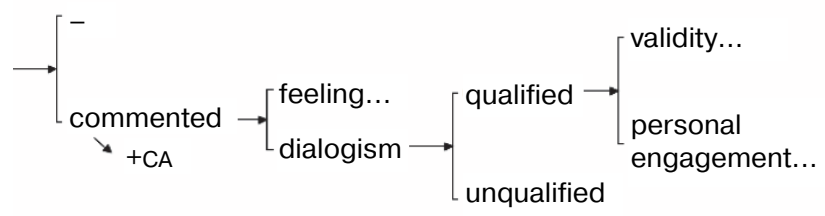

Fig. 5: Comment Adjunct systems

(cf. Halliday \& Matthiessen 2014)

The personal engagement class is then divided, without explanation, into [honesty] (e.g. frankly), [secrecy] (e.g. confidentially), [individuality] (e.g. personally), [accuracy] (e.g. strictly) and [hesitancy] (tentatively). The last of these categories, hesitancy, has only one realisation - tentatively. This means that we have reached the point where we can in fact lexicalise the realisation of the feature [hesitancy] as the lexical item tentatively. This additional delicacy is formalised in Fig. 6 below (with the feature [qualified] from Fig. 5 as its point of origin); the realisation statement CM::tentatively specifies the realisation of the feature [hesitancy] as the lexical item tentatively.

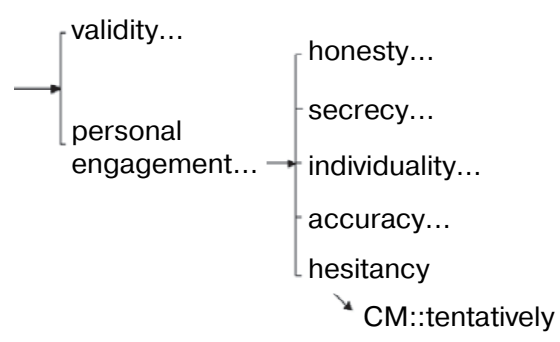

Fig. 6: Comment Adjunct systems, further delicacy

In effect what SFL is doing here is treating the relation between function words like $d o$ and open class lexical items like most nouns and verbs as a cline. From a paradigmatic perspective the difference is simply that function words realise grammatical options that are more general in delicacy than those realised by lexical items. In English, $d o$ for example is part of the realisation of general choices in MOOD, [negative] and [imperative] for example (i.e. Don't look now!); tentatively on the other hand realises more delicate options - via the realisation path [major: indicative: commented: dialogism: qualified: personal engagement: hesitancy].

Note particularly that Halliday \& Matthiessen motivate the [feeling/dialogism] opposition via interaction with MOOD and the [qualified/unqualified] distinction via potential combination with speaking, but that no criteria are offered for [validity] vs [personal engagement]. Similarly, no grounds are offered for differentiating types of personal engagement. This reflects a general problem as far as argumentation is concerned, namely 
that as we move from relatively closed system items to word classes with more members, the kind of motivations for features we are used to deploying for more general 'grammar' systems get harder to find.

\section{CONTINUING THE STUDY OF LEXIS: ATTITUDE}

In section 4 above we exemplified the way in which an analysis of feeling can be approached from the perspective of lexis as delicate grammar. Significantly, this meant taking one dimension of grammar (indicative mood to be precise) as a starting point and asking how Comment Adjuncts can be deployed to negotiate an attitude towards a declarative or interrogative clause - for example Sadly, they lost. But unhappiness can be realized through a number of grammatical resources, not just Comment Adjuncts. Across languages, nominal groups appear to provide the richest lexical resources for expressing feeling, through attitudinal Epithets (e.g. a sad fan). But feelings can also be realized as Circumstances of manner (e.g. they walked home sadly), and as mental processes (e.g. the loss distressed them) or behavioural ones (they frowned).
a sad fan
(nominal group Epithet)
they walked home sadly
(Manner circumstance)
the loss distressed them
(mental process)
they frowned
(behavioural process)

And grammatical metaphor can of course be deployed to reconstrue any of these realisations of unhappiness as a Thing in a nominal group:

It is with great sadness that I have to inform you that they lost.

The fans' sadness...

They walked home in sadness.

Their distress at the loss...

Their frown...

This means that as far as feeling is concerned the grammarian's dream has to be pursued in several regions of a grammar, each it must be acknowledged with a distinctive set of relational resources for negotiating feeling. That said, positioning lexis as delicate grammar means we cannot in lexicogrammar generalise the kinds of attitude that may be realised across different lexicogrammatical systems. To capture these generalisations we have to move up a level in abstraction to discourse semantics and make room for APPRAISAL. We move in other words from the grammarian's dream to a discourse analyst's nightmare!

Not knowing quite where else to turn, our basic strategy for proposing attitudinal relations was to lean on grammar, implicitly based on the feeling that if the grammar can be bothered generalising parameters related to evaluation, they might prove useful. Note in passing the assumption here of a 'natural' relation between lexicogrammar and discourse semantics at play, in relation to SFL's conception of a stratified content plane 
(as lexicogrammar and discourse semantics in a model such as that proposed in Martin 1992 and assumed in Martin \& Rose 2003/2007 and here). Although we will focus on just AFFECT at this point in the discussion, space precludes a detailed presentation of the relevant grammatical parameters. In short, as summarized in Table 1 below, our [irrealis/realis] opposition derives from the distinction between desiderative and emotive mental process (I wanted them to win/I like them winning); our [desire/fear] opposition from the distinction between positive and negative expanding purpose clauses (They played aggressively so that they'd win/they played conservatively lest they lose); our [surge/disposition] opposition from the distinction between behavioural and mental processes (I cried when they lost/It upset me that they lost); our [mood/directed at] opposition from the distinction between relational and mental processes (I felt sad (but wasn't sure what made me feel that way)/The loss upset me); our [high/median/low] opposition on MODALITY (They're certainly/probably/possibly upset); and our [positive/ negative] opposition on POLARITY (I was/wasn't sad).

Table 1

Grammatical sources for AFFECT relations

\begin{tabular}{|l|l|l|}
\hline \multicolumn{1}{|c|}{ discourse semantics } & \multicolumn{1}{c|}{ lexicogrammar } & \multicolumn{1}{c}{ relevant valeur } \\
\cline { 1 - 2 } AFFECT & & \\
\hline irrealis/realis & PROCESS TYPE & desiderative/emotive \\
\hline desire/fear & EXPANSION & purpose so that/lest \\
\hline surge/disposition & PROCESS TYPE & behavioural/mental \\
\hline mood/directed at & PROCESS TYPE & relational/mental \\
\hline high/median/low & MODALITY & median/outer: high/low \\
\hline positive/negative & POLARITY & positive/negative \\
\hline
\end{tabular}

This left us with the problem of sorting out kinds of emotion, for which the grammar didn't seem to be offering generalizable support. I was parenting a small child at the time and suggested categories based on my reading of his emotional repertoire in relation to his parents coping (or not) with his moments of distress — basically asking whether he was unhappy because he wanted his mother or father (contented sociability), or because he wanted the comfort of his security blanket (which he called 'baggy'), or because he wanted the satisfaction of his bottle ('bopple'). This gave us the [unhappiness/happiness], [insecurity/security] and [dissatisfaction/satisfaction] oppositions outlined in Table 2.

Table 2

Additional AFFECT parameters

\begin{tabular}{|l|l|l|}
\hline & \multicolumn{1}{|c|}{ 'parenting' } & \multicolumn{1}{c|}{ 'space grammar' } \\
\hline un/happiness & Mummy/Daddy & bonding \\
\hline in/security & baggy & binding \\
\hline dis/satisfaction & bopple & promenade \\
\hline
\end{tabular}

In retrospect, if work on space grammar had already been available at the time, I might equally well have drawn on Stenglin's (e.g. 2009) notions of bonding (in relation to [un/happiness]) and binding (in relation to [in/security]), and McMurtrie's (e.g. 2013) concept of promenade (in relation to the telos oriented notion of [dis/satisfaction]). 
The oppositions reviewed in Tables 1 and 2 above are consolidated typologically ${ }^{5}$ as a system network in Fig. 7 below, with the strength of a feeling, [high/median/low], treated as a clined system. Since we are focusing on AFFECT in this paper I've labelled the $[\mathrm{mood} /$ directed at opposition introduced above as a [moody/triggered] system.

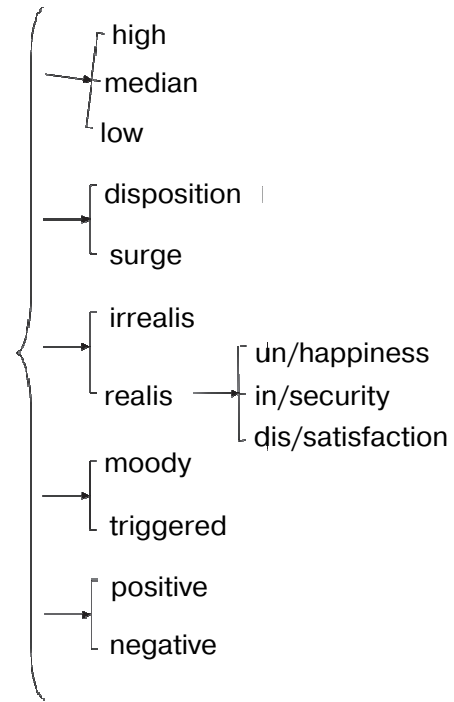

Fig. 7: English AFFECT systems (after Martin \& White 2005)

In Martin \& White 2005 these oppositions were presented in the form of paradigms, in spite of the number of simultaneous dimensions ${ }^{6}$ involved. For AFFECT, [ir/realis], [un/happiness], [in/security] and [dis/satisfaction] feelings were presented in separate tables such as that illustrated for [un/happiness] below. The [surge/disposition] opposition was used for columns and the [positive/negative] opposition for rows; then, by subdividing rows, moods were opposed to directed feelings (the [moody/triggered] opposition in Fig. 7); and by further subdividing these subdivisions feelings were scaled as [positive/negative] and as [high/median/low]. The table cells formed through this organization were then used to exemplify the feeling at play; the lexical item sad in Table 3 for example represented a feeling negotiated in terms of the features [median], [disposition], [realis: un/happiness], [moody] and [negative]. As noted in section 3 above, this degree of dimensionality severely strains the paradigm as a tool for representing oppositions. Paradigms like that in Table 3 do however offer a relational overview of the feelings at play, even if they are restricted to focusing on one part or another of the range of emotions negotiated verbally in discourse at a time.

5 As noted in Martin \& White 2005: 48, irrealis feelings are always triggered, and so the features [irrealis] and [triggered] need to be tied together using a conditional marking convention in a more precise representation.

${ }^{6}$ This presentation strategy in effect involves taking the type of feeling as a first cut (irrealis, un/happiness, insecurity, dis/satisfaction), cross-classifying each feeling as [positive/negative] and [surge/disposition], and subclassifying the resulting cells as [moody/triggered] and as [high/median/ low] — imposing delicacy, for practical display purposes, where there is none. 
English AFFECT oppositions for [un/happiness]

(Martin \& White 2005)

\begin{tabular}{|c|c|c|c|}
\hline & [surge] (of behaviour) & \multicolumn{2}{|c|}{ [disposition] } \\
\hline \multirow{2}{*}{$\begin{array}{l}\text { [unhappiness/moody] } \\
\text { 'misery' } \\
\text { [unhappiness/triggered] } \\
\text { 'antipathy' }\end{array}$} & $\begin{array}{l}\text { whimper } \\
\text { cry } \\
\text { wail }\end{array}$ & $\begin{array}{l}\text { down } \\
\text { sad } \\
\text { miserable }\end{array}$ & $\begin{array}{l}\text { [low] } \\
\text { [median] } \\
{[\text { high] }}\end{array}$ \\
\hline & $\begin{array}{l}\text { rubbish } \\
\text { abuse } \\
\text { revile }\end{array}$ & $\begin{array}{l}\text { dislike } \\
\text { hate } \\
\text { abhor }\end{array}$ & \\
\hline \multirow{2}{*}{$\begin{array}{l}\text { [happiness/moody] } \\
\text { 'cheer' } \\
\text { [happiness/triggered] } \\
\text { 'affection' }\end{array}$} & $\begin{array}{l}\text { chuckle } \\
\text { laugh } \\
\text { rejoice }\end{array}$ & $\begin{array}{l}\text { cheerful } \\
\text { buoyant } \\
\text { jubilant }\end{array}$ & \\
\hline & $\begin{array}{l}\text { shake hands } \\
\text { hug } \\
\text { cuddle }\end{array}$ & $\begin{array}{l}\text { fond } \\
\text { loving } \\
\text { adoring }\end{array}$ & \\
\hline
\end{tabular}

As indicated in Table 3 Martin \& White also provided consolidating cover terms for the intersection of choices from the [irrealis/realis], [moody/triggered] and [positive/negative] systems. So 'misery' in Table 3 above stands as a cover term ${ }^{7}$ for [un/happiness, moody, negative], 'antipathy' for [un/happiness, triggered, negative], 'cheer' for [un/happiness, moody, positive] and 'affection' for [un/happiness, triggered, positive]. It is important to note that these terms are not lexical items exemplifying the realization of discourse semantic features; they are in fact a short-hand for specific ATTITUDE oppositions. For the remainder of this paper I enclose these feature consolidating discourse semantic terms in single quotes to help avoid confusing them with the lexical items which realize them.

In order to emphasise that the lexical items included in the paradigms were simply graded examples of relevant realisations, Martin \& White 2005: 51 drew on Roget's Thesaurus to illustrate the range of alternatives at play, focusing on moody unhappiness. This cell is blown up in Table 4 below (although by no means exhaustively), and gives us some indication of the scope of the task of developing the description of AFFECT to the point where it differentiates all the core and non-core lexical items realizing unhappiness from one another. It is also important to clarify at this point that the lexical items in the paradigms exemplify how discourse semantic systems are realised in lexicogrammar; the paradigms thus relate one stratum of meaning to another.

Table 4

A range of realisations for unhappiness (drawing on Roget's Thesaurus)

\begin{tabular}{|l|l|l|}
\hline \multicolumn{1}{|c|}{ affect } & \multicolumn{1}{|c|}{ [positive] } & \multicolumn{1}{c|}{ [negative] } \\
\hline $\begin{array}{l}\text { [un/happiness] } \\
\text { cheer/misery' }\end{array}$ & $\begin{array}{l}\text { cheerful, buoyant, jubilant; } \\
\text { fond, loving, adoring }\end{array}$ & $\begin{array}{l}\text { sad, melancholy, despondent; cut-up, heart-broken... } \\
\text { broken-hearted, heavy-hearted, sick at heart; sorrowful... } \\
\text { grief-stricken, woebegone... dejected...; dejected, joyless, } \\
\text { dreary, cheerless, unhappy, sad; gloomy, despondent, ... } \\
\text { downcast, low, down, down in the mouth, depressed...; } \\
\text { weepy, wet-eyed, tearful, in tears.. }\end{array}$ \\
\hline
\end{tabular}

7 These cover terms are comparable to Halliday \& Matthiessen's 2014: 136 use of terms like statement to consolidate the speech function features [give, information]. 


\section{CORPUS BASED ARGUMENTATION}

In section 4 above I raised the issue of motivating features in delicate lexicogrammatical systems; the same kind of problem arises for discourse semantic ones. One possible recourse is to bring corpus evidence to bear on classification schemes, as exemplified in Bednarek 2008. We'll deal with her discussion of 'fear' and 'surprise' here.

The relevant paradigm for her discussion of 'fear' is presented as Table 5 below. For Martin \& White the [positive/negative] opposition at play here is between emotional reactions to things we want to happen and things we don't - between 'desire' and 'fear'. As far as surges of 'desire' are concerned, they suggest verbal process realisations graded according to the strength of the feeling they invoke.

Irrealis AFFECT systems (Martin \& White 2005)

Table 5

\begin{tabular}{|l|l|l|}
\cline { 2 - 3 } \multicolumn{1}{c|}{} & \multicolumn{1}{c|}{ [surge] (of behaviour) } & \multicolumn{1}{c|}{ [disposition] } \\
\hline $\begin{array}{l}\text { [disinclination] } \\
\text { 'fear' }\end{array}$ & $\begin{array}{l}\text { tremble } \\
\text { shudder } \\
\text { cower }\end{array}$ & $\begin{array}{l}\text { wary (have qualms/scare) } \\
\text { fearful (fear/frighten) } \\
\text { terrified (dread/terrify) }\end{array}$ \\
\hline $\begin{array}{l}\text { [inclination] } \\
\text { 'desire' }\end{array}$ & $\begin{array}{l}\text { [suggest] } \\
\text { [request] } \\
\text { [implore] }\end{array}$ & $\begin{array}{l}\text { lonely (long for) } \\
\text { bereft (yearn for) }\end{array}$ \\
\hline
\end{tabular}

On the basis of corpus evidence Bednarek argues that realisations of 'fear' combine freely with triggers that are already present (e.g. the noise frightened her) and that such emotions are therefore not irrealis. As a first step in exploring this concern let's deal with the labeling issue. As noted above, the grammatical opposition inspiring the [realis/ irrealis] affect opposition does indeed involve what linguists regularly term irrealis meaning. In an enhancing clause complex context the opposition is clearly between what we want to happen and what we don't - positive and negative 'purpose' if you will.

I studied so that I'd pass : lest I fail ::

I studied because I wanted to pass : out of fear of failing 8

This grammatical opposition is then recontextualised by Martin \& White to oppose feelings about what we do and don't want to happen to others. Since the terms realis and irrealis hadn't in fact been set up as features in Halliday's functional grammar (e.g. Halliday \& Matthiessen 2014) they adopted the terms. It is in this discourse semantics context that they suggest that 'fear' (i.e. [irrealis/negative/triggered] emotion) concerns what might happen or not, not whether a trigger is materially present or not. In other words, when someone frightens us, are we afraid of them, or are we afraid because of what they might do? It follows that the most likely reading of It frightened me that he'd come, to my mind, is 'it frightened me that he would come', not 'it frightened me that he had come'. For It startled me that he'd come on the other hand, which realizes 'surprise' (i.e. triggered realis insecurity), the most likely reading, to my mind, is 'it startled me he had come', not 'it startled me he would come.' The alternative readings are possible; but It frightened me that he had come implies, for me, fear about what he might do. Similarly, It startled me that he would come makes sense, for me, in a context where it implies that it was hearing the news that he would come that startled me.

${ }^{8}$ The punctuation here, $\mathrm{a}: \mathrm{b}:: \mathrm{c}: \mathrm{d}$, formalizes the proportionality ' $\mathrm{a}$ ' is to ' $\mathrm{b}$ ' as ' $c$ ' is to 'd'. 
We also need to keep in mind at this point in the discussion that in a relational theory of meaning removing 'fear' from negative irrealis affect ${ }^{9}$ means putting it somewhere else - re-grouping it perhaps as a parameter of insecurity. At stake here is our reading of a text like the following, from a children's picture book (Wolfer \& HarrisonLever 2005). Martin \& White would read shock as realizing insecurity, in relation to the soldiers having been wounded, and terror as realizing 'fear', in relation to what might come (pain, death, capture, defeat etc.). Reworking 'fear' as a dimension of insecurity raises the question of how exactly shock differs from terror, in terms of force perhaps (high, median, low) or some other yet to be established parameter.

Jack fired his gun. He saw shock and terror in the Japanese soldier's eyes as they fell. Jack wanted to drop his rifle and cover his ears, but it was impossible to block the cries of the injured and dying men. [Wolfer \& Harrison-Lever 2005]

My basic point here is that labeling is not defining. Terms for classifying AFFECT have to come from somewhere, and we don't in linguistics have much terminological heritage to draw on in this regard. A term like irrealis needs to be carefully interpreted with regard to the realis feelings it opposes (not just in terms of the meaning of imperfective and perfective clauses in the grammar of ASPECT), just as a term like positive has to be interpreted in relation to the negative feelings it opposes (not simply in terms of positive or negative POLARITY and the grammar of MOOD). So what we really need to know from corpus evidence is not whether a trigger is materially present or not as far as realisations of 'fear' are concerned, but whether 'fear' can be shown (or not) to be about what might happen - as opposed to 'surprise', which is arguably about what has already occurred. How exactly such a study might be formulated as a piece of corpus research I am not sure.

Another of Bednarek's concerns has to do with 'surprise', specifically with whether it in fact realizes negative in/security. The relevant dimensions of insecurity are outlined in Table 6 below.

Table 6

English AFFECT oppositions for [in/security] (Martin \& White 2005)

\begin{tabular}{|l|l|l|}
\cline { 2 - 3 } \multicolumn{1}{c|}{} & \multicolumn{1}{c|}{ [surge] (of behavior) } & \multicolumn{1}{c|}{ [disposition] } \\
\hline $\begin{array}{l}\text { [insecurity/moody] } \\
\text { 'disquiet' }\end{array}$ & $\begin{array}{l}\text { restless } \\
\text { twitching } \\
\text { shaking }\end{array}$ & $\begin{array}{l}\text { uneasy } \\
\text { edgy } \\
\text { insecurity/triggeaked out }\end{array}$ \\
\cline { 2 - 3 } 'surprise' & $\begin{array}{l}\text { start } \\
\text { cry out } \\
\text { faint }\end{array}$ & $\begin{array}{l}\text { disturbed(bother) } \\
\text { startled (hassle) } \\
\text { shattered (harass) }\end{array}$ \\
\hline [security/moody] & $\begin{array}{l}\text { [declare] } \\
\text { [assert] } \\
\text { 'confidence' }\end{array}$ & $\begin{array}{l}\text { together } \\
\text { confident } \\
\text { assured }\end{array}$ \\
\cline { 2 - 3 } [security/triggered] & $\begin{array}{l}\text { [delegate] } \\
\text { [commit] } \\
\text { 'trust' }\end{array}$ & $\begin{array}{l}\text { comfortable with } \\
\text { confident in/about } \\
\text { trusting }\end{array}$ \\
\hline
\end{tabular}

9 Note that Bednarek is not proposing removing the category of negative irrealis affect entirely, which would be realized through lexis involved unwillingness (e.g. reluctant, disinclined, unwilling; refuse); this involves interpreting negative dis/inclination rather literally, in terms of a grammatical understanding of POLARITY, as 'not inclined'. 
For Bednarek, 'surprise' seems to be the odd term out if we expect positive and negative emotions to, in her terms, 'mirror' one another:

$$
\begin{aligned}
& \text { ‘cheer' : ‘misery':: 'affection' : 'antipathy':: } \\
& \text { ‘interest' : ‘ennui' :: 'pleasure' : 'displeasure' :: } \\
& \text { 'confidence' : 'disquiet' } \neq \text { 'trust' : 'surprise' }
\end{aligned}
$$

This may simply be a question of labeling. Would the following revision help make the negative terms correspond more proportionally to one another?

$$
\begin{aligned}
& \text { ‘cheer' : ‘misery' :: ‘affection' : ‘antipathy' :: } \\
& \text { 'interest' : 'ennui' :: 'pleasure' : 'displeasure' :: } \\
& \text { 'confidence' : ‘nervousness' :: ‘trust' : 'perturbance' }
\end{aligned}
$$

But is 'surprise' in fact [negative]? Bednarek argues this discourse semantic category is not, drawing on the following pieces of corpus evidence.

i. the lexical item surprise is associated, as a noun, verb and adjective, with behavioural surges related to both positive and negative emotions:

squeals (delight)

laughter, smiles (delight, pleasure, affection)

screams, shouts (fear)

wide eyes (fear)

freezing (fear)

ii. the lexical item surprise is conjoined paratactically equally with both positive and negative emotion terms:

relief and surprise, surprise and admiration, surprise and pleasure, surprised and interested

embarrassment and surprise, fear and surprise, sad and surprised, surprised and irritated

iii. the lexical item surprise is associated with positive volition:

hoping to surprise, wanted to surprise, urge someone to surprise, it would be nice to surprise

iv. as an Epithet, the lexical item surprise can modify both positive and negative lexis

\section{surprise party/surprise attack}

Taking the lack of 'mirroring', and corpus evidence from i-iv into account, Bednarek argues 'surprise' should be removed from [in/security] and set up as a separate category of AFFECT. Her proposed revision is outlined in Fig. 8 below.

Bednarerk's use of corpus evidence in relation to classifying AFFECT is an important step as far as developing argumentation in relation to categorizing meanings is concerned and lays the foundation for important developments along various lines. 


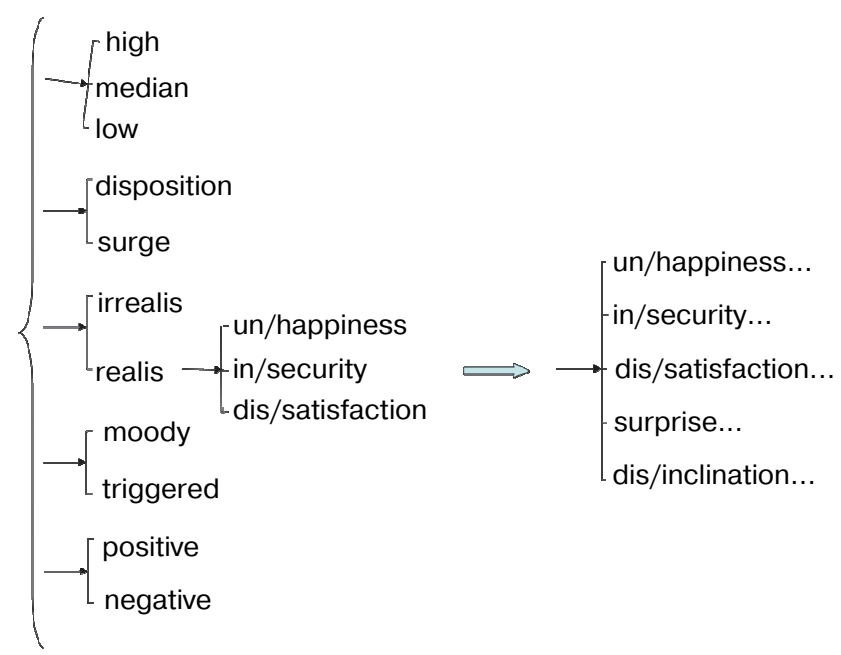

Fig. 8: Bednarek's 2008 revision of AFFECT categories

One important issue that immediately arises however is that of core and non-core lexis. All of Bednarek's 2008 examples in relation to the discourse semantic category 'surprise' are in fact for the lexical item surprise, with one exception (shock, which in fact has negative associations). A stronger case for re-categorisation could be made if a wide range of realisations were considered, showing for example that all of the following realisations of 'surprise' are associated with both positive and negative emotion terms (a pattern of association I would find quite surprising):

disturbed, shocked, unsettled, stunned, astounded, shaken, rattled, shattered, staggered, thrown, taken aback, bowled over, caught unawares, caught napping, caught off one's guard, jolted, dazed.

The problem here is that we don't yet have corpora big enough to give enough examples of this range of realisations. Surprise was apparently the only lexical item which occurred frequently enough for Bednarek to establish patterns. As far as ATTITUDE is concerned, a large corpus of spoken pre-school discourse revealing the ontogenesis of core attitudinal lexis would be ideal - by way of extending Painter's case study (2003). Data of this kind is unfortunately the most costly kind of data to compile and one of the more unlikely kinds of data to be funded by commercial interests.

It would also be useful to know what effect the corpus linguistic concept of 'semantic prosody' (e.g. Stewart 2010) has on particular lexical items. Does the occurrence of the lexical item surprise in recurrent evaluations such as what a nice surprise, or a surprising success, mean that a positive appreciation of a thing or event in some sense rubs off on this particular lexical item and is over time in part responsible for the mixed positive/negative associations for surprise in Bednarek's corpus?

\section{A TOPOLOGICAL PERSPECTIVE}

Since the promise of corpus-based argumentation seems unlikely to be fulfilled in the short term, due to lack of appropriate data (and enough researchers to thoroughly explore the data we have!), in this section I'll explore a topological perspective on ATTI- 
TUDE a little further - as one possible direction in which we might continue the study of lexis. We'll begin with the feelings outlined as a paradigm in Table 3 above. The feelings there are reconfigured as a topology in Fig. 9 below, privileging the [positive/negative] and [surge/disposition] oppositions as axes. The lexical items used in Table 3 to exemplify the realisation of the relevant feelings have been positioned in the relevant region of the topology.

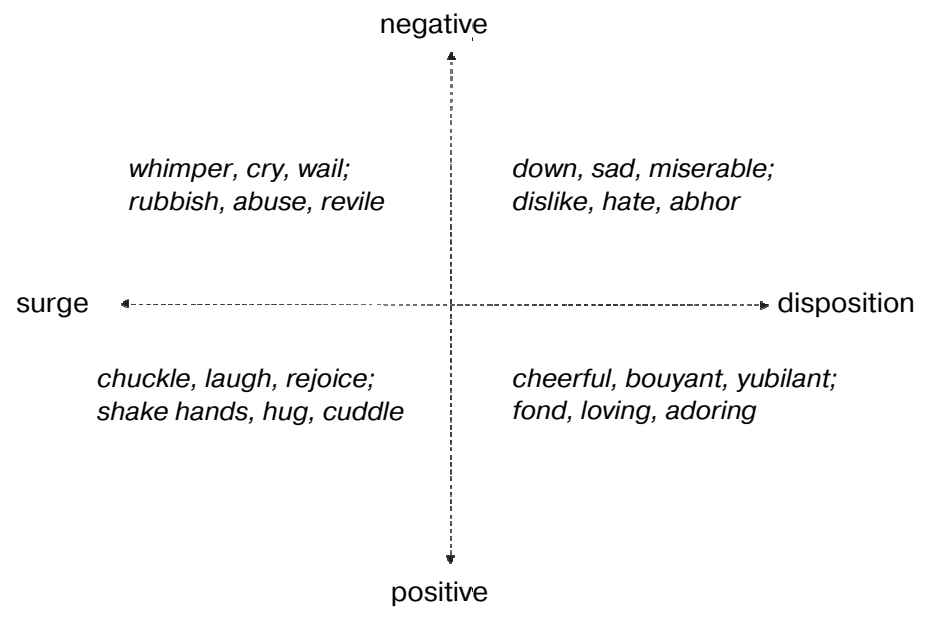

Fig. 9: ATTITUDE topology for [un/happiness]

If we then home in on the [negative/disposition] region of the topology (its upper right quadrant), the force of the feelings and the [moody/triggered] opposition can be privileged as axes (Fig. 10 below). This allows us to arrange lexical items exemplifying feelings on a cline from high to low (e.g. miserable, sad, down; abhor, hate, dislike), and makes room for additional realisations (not specified in Fig. 10), arranged by degree at different points along the horizontal axis.

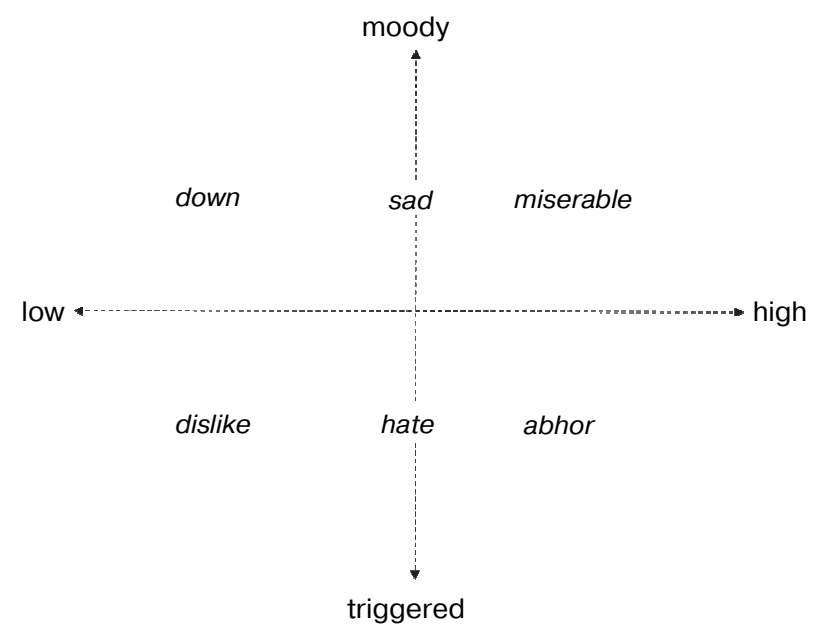

Fig. 10: ATTITUDE topology for [negative/disposition] feelings

This gets us in position to begin to tackle the range of realisations of moody AFFECT introduced in Table 4 above. We'll focus on high values in Fig. 11 (homing in once again on the upper right quadrant). At this point we need to move beyond the oppositions 
presented in Table 3. The horizontal axis proposes a relational parameter opposing embodied feelings (e.g. heart-broken, gutted) to general ones (e.g. mournful, despondent), where the embodied feelings are lexicalized in relation to some dimension of human physiology. The vertical axis proposes a relational parameter opposing feelings of loss about something we had (e.g. heart-broken, mournful) to feelings of failure about something we didn't achieve (e.g. gutted, dejected). General feelings (e.g. wretched, miserable) which might be associated with either loss or frustration can then be positioned at a half-way point on the vertical axis.

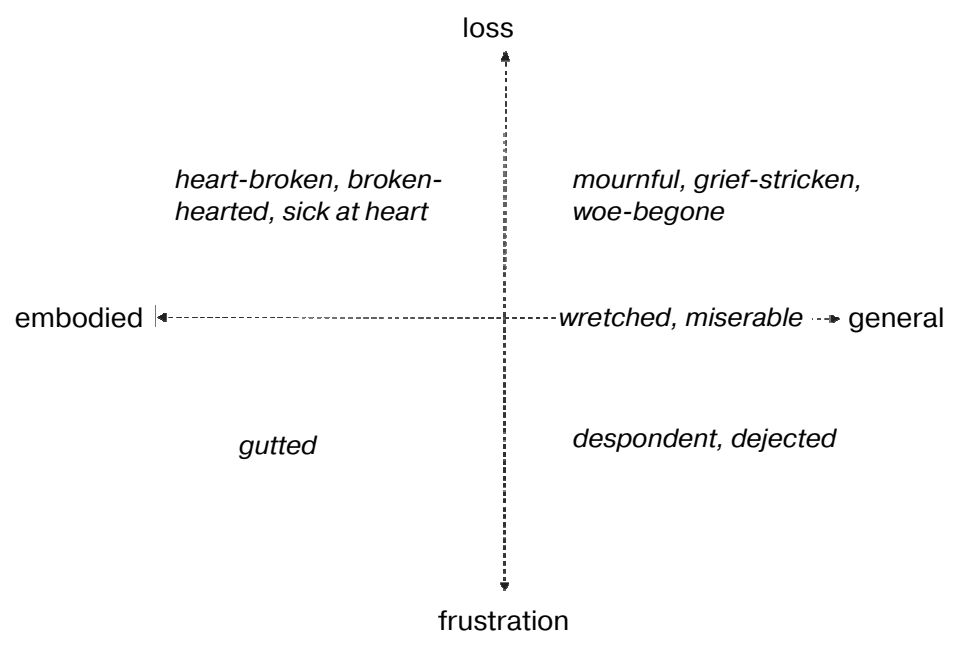

Fig. 11: ATTITUDE topology for [high/moody] feelings

I won't pursue development of this topology any further here. The critical problem has to do with proposing appropriate axes on the basis of arguable oppositions among lexical items. As Bednarek has shown, the nature of triggers is potentially criterial; can we find corpus evidence to show that we feel grief-stricken about something we have had and lost, but despondent about something we wanted but never got (a 'better to have loved and lost than never to have loved at all' opposition)? And pending corpus evidence, can we set up convincing frames to test the relevance of an axis?

He was grief-stricken about her death.

?He was grief-stricken about having failed.

He was despondent about having failed.

?He was despondent about her death.

A key problem here is that examples seem more or less likely, rather than clearly 'right' or 'wrong', so that the grammarian's strategy of exploring grammatical and ungrammatical structures to define the meaning potential of a language is very awkward to deploy. Perhaps the best we can do at this stage is to propose topologies for regions of attitude that serve discourse analysts' needs, as part of their focus on one or another register, in relation to one or another practical concern.

In this regard let's consider an unusual set of lexis that Martin \& White (2005: 60) propose as arguably realising both AFFECT and JUDGEMENT, which they exemplify as follows: guilty, embarrassed, proud, jealous, envious, ashamed, resentful, contemptu- 
ous.... This region of meaning deals in particular with emotional reactions to social behaviour, most of which are oriented to disaffiliation (i.e. social bonds at risk; for discussions of bonding in relation to identity in SFL see Stenglin 2009, Knight 2013, Martin 2010b, Martin et al 2013). Within this set proud seems to be the odd term out, since it enacts satisfaction with one's achievements in positive ${ }^{10}$ terms; the other terms negotiate negative reactions to behavior.

As far as the negative reactions are concerned, a number of possible axes of opposition suggest themselves here. Table 7 proposes an analysis organizing types of reaction as [irrealis], [un/happinesss], [in/security] or [dis/satisfaction] and as [positive] or [negative]. What is interesting here is that the 'positive' reactions are positioned as excessive - as inappropriate desire (e.g. jealous), inappropriate affection (e.g. dote on), inappropriate trust (e.g. credulous) or inappropriate pleasure (e.g. smug; awestruck). The negative irrealis reactions also focus on excess (e.g. paranoid as 'too fearful'); the realis reactions are triggered by misbehavior and/or flawed character.

Table 7

Negative and excessively positive reactions to behavior/character

\begin{tabular}{|c|c|c|c|c|}
\hline & \multirow[t]{2}{*}{ [irrealis] } & \multicolumn{3}{|c|}{ [realis] } \\
\hline & & [un/happinesss] & [in/security] & [dis/satisfaction] \\
\hline $\begin{array}{l}\text { [positive] } \\
\text { 'excess' }\end{array}$ & $\begin{array}{l}\text { 'desire': jealous, } \\
\text { envious, covet }\end{array}$ & idolize, dote on & $\begin{array}{l}\text { unsuspecting, } \\
\text { credulous }\end{array}$ & $\begin{array}{l}\text { complacent, overconfident; } \\
\text { smug, gloat; overawed, } \\
\text { awestruck }\end{array}$ \\
\hline [negative] & $\begin{array}{l}\text { 'fear': paranoid, } \\
\text { phobic; daunted, } \\
\text { intimidated }\end{array}$ & $\begin{array}{l}\text { resentful, aggrieved; } \\
\text { contemptuous, dis- } \\
\text { dainful }\end{array}$ & embarrassed & $\begin{array}{l}\text { guilty, ashamed, remorseful; } \\
\text { indignant }\end{array}$ \\
\hline
\end{tabular}

The misbehaviour and/or flawed character triggering these reactions may relate either to behavior and character for which the emoter is responsible, or to behavior and character beyond their purview. Reactions are reclassified in these terms in Table 8 below. The analysis for irrealis reactions suggests opposing fears about what one has to do (daunted, intimidated) to fears about what someone else might do (paranoid, phobic), even though in both cases someone or something else triggers the fear.

Table 8

\section{Reactions to one's own vs other's behavior/character}

\begin{tabular}{|l|l|l|l|l|}
\cline { 3 - 5 } \multicolumn{1}{c|}{} & \multicolumn{2}{c|}{ [irrealis] } & \multicolumn{3}{c|}{ [realis] } \\
\cline { 3 - 5 } \multicolumn{1}{c|}{} & \multicolumn{1}{c|}{ [un/happinesss] } & [in/security] & \multicolumn{1}{c|}{ [dis/satisfaction] } \\
\hline $\begin{array}{l}\text { One's own } \\
\text { behavior/ } \\
\text { character }\end{array}$ & $\begin{array}{l}\text { daunted, } \\
\text { intimidated }\end{array}$ & dote on & embarrassed & $\begin{array}{l}\text { complacent, overconfident; } \\
\text { smug, gloat; } \\
\text { guilty, ashamed, remorseful }\end{array}$ \\
\hline $\begin{array}{l}\text { others' } \\
\text { behavior/ } \\
\text { character }\end{array}$ & $\begin{array}{l}\text { paranoid, phobic; } \\
\text { jealous, envious, } \\
\text { covet }\end{array}$ & $\begin{array}{l}\text { idolize; resentful, } \\
\text { aggrieved; contemp- } \\
\text { tuous, disdainful }\end{array}$ & $\begin{array}{l}\text { unsuspecting } \\
\text { credulous } \\
\text { overawed, awestruck }\end{array}$ \\
\hline
\end{tabular}

10 That said, in western culture pride is a dangerous emotion; enacting too much pride in the wrong place at the wrong time quickly invites censure and accusations of arrogance. 
As a final step, as far as the analysis here is being pursued, Table 9 considers the kind of judgements ${ }^{11}$ triggering the reactions canvassed in Tables 7 and 8 . The Table suggests that reactions and judgements do not freely combine, but in the absence of corpus evidence it is hard to know whether we are talking about tendencies or categorical distinctions. For example, the Table proposes that we can feel aggrieved about someone else's dishonesty or impropriety (social sanction), but not about their cowardice, stupidity or misfortune (social esteem). What, one day, might a corpus large enough to reveal patterns about non-core items such as aggrieved tell us about how they are in fact used?

Table 9

Reactions to judgements of one's own vs other's behavior/character

\begin{tabular}{|c|c|c|c|c|c|}
\hline & \multicolumn{3}{|c|}{ [social esteem] } & \multicolumn{2}{|c|}{ [social sanction] } \\
\hline & [normality] & [capacity] & [tenacity] & [veracity] & [propriety] \\
\hline $\begin{array}{l}\text { one's own } \\
\text { achievements }\end{array}$ & $\begin{array}{l}\text { embarrassed; } \\
\text { complacent, } \\
\text { overconfident; } \\
\text { smug, gloat }\end{array}$ & $\begin{array}{l}\text { daunted, in- } \\
\text { timidated; } \\
\text { embarrassed; } \\
\text { complacent, } \\
\text { overconfident; } \\
\text { smug, gloat }\end{array}$ & $\begin{array}{l}\text { daunted, intim- } \\
\text { idated; } \\
\text { embarrassed; } \\
\text { smug, gloat; } \\
\text { guilty, } \\
\text { ashamed, } \\
\text { remorseful }\end{array}$ & $\begin{array}{l}\text { embarrassed; } \\
\text { guilty, } \\
\text { ashamed, } \\
\text { remorseful }\end{array}$ & $\begin{array}{l}\text { embarrassed; } \\
\text { guilty, } \\
\text { ashamed, } \\
\text { remorseful }\end{array}$ \\
\hline $\begin{array}{l}\text { others' } \\
\text { achievements }\end{array}$ & $\begin{array}{l}\text { dote on; } \\
\text { paranoid, } \\
\text { phobic; } \\
\text { resentful; } \\
\text { overawed, } \\
\text { awestruck }\end{array}$ & $\begin{array}{l}\text { dote on, idol- } \\
\text { ize; } \\
\text { paranoid, } \\
\text { phobic; } \\
\text { jealous, envi- } \\
\text { ous, covet; } \\
\text { idolize; } \\
\text { resentful; } \\
\text { overawed, } \\
\text { awestruck }\end{array}$ & $\begin{array}{l}\text { idolize; } \\
\text { paranoid, pho- } \\
\text { bic; } \\
\text { jealous, envi- } \\
\text { ous, covet; } \\
\text { idolize; } \\
\text { resentful; } \\
\text { contemptuous, } \\
\text { disdainful; } \\
\text { indignant; } \\
\text { overawed, } \\
\text { awestruck }\end{array}$ & $\begin{array}{l}\text { idolize; } \\
\text { resentful, } \\
\text { aggrieved; } \\
\text { contemptuous, } \\
\text { disdainful; } \\
\text { credulous; } \\
\text { indignant; } \\
\text { overawed, } \\
\text { awestruck }\end{array}$ & $\begin{array}{l}\text { idolize; } \\
\text { resentful, } \\
\text { aggrieved; } \\
\text { contemptuous, } \\
\text { disdainful; } \\
\text { unsuspecting; } \\
\text { indignant; } \\
\text { overawed, } \\
\text { awestruck }\end{array}$ \\
\hline
\end{tabular}

As Table 9 in effect acknowledges, the lexical items negotiating feeling in this region of meaning can arguably be double-coded as inscribing both AFFECT and JUDGEMENT. The possibility of blending thus acknowledged, it is important to note that these items generally fit snugly into our most effective colligational frame for AFFECT and are out of place in our most effective one for JUDGEMENT; it is this patterning that underlies the inscribed AFFECT, invoked JUDGEMENT analysis suggested in Martin \& White 2005: 68):

I felt angry that I did that.

AFFECT

I felt guilty that I did that.

It was brave of them to do that.

JUDGEMENT

*It was guilty of them to do that.

Reviewing this exercise, a number of points arise from the proposals encoded in Tables 7, 8 and 9- many of which call Malinowski's comments on the 'gaps, gluts

${ }^{11}$ For the JUDGEMENT systems assumed here see Tables 10 and 11 in Appendix 1. 
and vagaries' of Trobriand Island gardening terminology to mind (1935: 65). As far as 'gaps and gluts' are concerned, the feelings at play here are overwhelmingly negative; pride is arguably the only 'feel good' reaction we negotiate about our achievements or others. Beyond this, as far as negative reactions are concerned, the cells in Tables 7, 8 and 9 are populated very differently — some with few realisations and others with several (the more populous cells of course call out for further exploration, probably along the lines of that modeled in Figures 9, 10 and 11 above). The teleological orientation of the affect category [dis/satisfaction] perhaps explains some of the skewing, since it deals with emotions arising from participation in one or another activity sequence. But a more general account of 'gaps and gluts' is well beyond, and perhaps forever beyond, our understanding of the contextual history of the lexical items involved. Perhaps a corpus revealing the ontogenesis of this region of meaning could give us a glimmer of understanding; but as noted above, corpora monitoring language development are currently prohibitively costly to assemble.

As far as 'vagaries' are concerned, the doubts I raised above about the placement of lexical realisations in Table 9 indicate the usefulness of a topological perspective alongside a typological one - since realisations can then be positioned along clined axes (e.g. as reacting to a greater or lesser extent to [normality], [capacity], [tenacity] and so on). That said I have not attempted a topological display for the meanings at stake in this region, in part because my account is a partial one, and in part because, in spite of this, there are several simultaneous axes already in play (i.e. types of AFFECT, positive or negative, in relation to one's own behavior or that of others, in relation to kinds of JUDGEMENT) - and I have no principled basis for privileging one or another of these axes in the kind of displays presented in Figures 9-11 above (where the privileging was equally arbitrary). As noted above, this is not a theoretical issue; a topology is in principle an ' $x$ '-dimensional space. Rather the problem is representational. What is needed perhaps is a form of electronic representation which allows different axes to be foregrounded, in effect affording multiple windows of perspective on the complex agnation involved. This would rework the arbitrary privileging of axes in Figures 9 through 11 as a question of perspective, in relation to a discourse analyst's concerns. For recent developments in representation moving beyond the affordances of a 2-dimensional diagram on page or screen see Almutairi 2013, Zappvigna 2011.

The multidimensionality involved here recalls van Leeuwen's work on what he calls parametric systems (van Leeuwen 2009, Martin 2011) — semiotic resources involving a number of simultaneous systems, consisting of two terms, which are graded in relation to one another. In his work on voice quality, colour and typography the systems tend to freely combine, and so a typological representation such as that introduced in Fig. 3 above is appropriate. The 'gaps and gluts' of lexical realisations means however that a representation of this kind overgeneralizes the meanings involved, proposing too many feature combinations that don't get realized and not providing enough delicacy for combinations that do. In this regard it is instructive to reflect on the complexity of the wiring in Hasan's 1987 lexis as delicate grammar initiative (e.g. her Fig. 4.2) where the possibilities afforded by simultaneous systems are all constrained with complex left-facing wiring so that only lexicalized meanings are realized. 


\section{A GRAMMARIAN'S VISION (AND BEYOND)}

In this paper we have explored some of the issues arising from what Halliday 1961 has characterized as the grammarian's dream of formalizing lexis as delicate grammar. As far as attitudinal lexis is concerned we have in fact shifted our focus from lexicogrammar to discourse semantics, in order to generalize across the range of systems enacting attitude - from the grammarian's dream to a discourse analyst's nightmare.

Why nightmare? My hunch is that the bad dreams derive in part from grammarians' vision of the nature of SFL as an L1. SFL's conceptual architecture is basically derived from work on grammar - on axial relations (the particular complementarity of system and structure engineered by Halliday and his colleagues in the 1960s) and the conception of rank, metafunction and stratification arising directly from SFL's distinctive privileging of paradigmatic relations (for foundational papers see Halliday $\&$ Martin 1981). Representation was a key part of this enterprise, with system networks evolving as a formalization of systemic relations - canonically for English clauses and verbal groups. Critically a tradition of cryptogrammatical reasoning (Davidse 1998) evolved which gave rise to networks cross-classifying a small number of more general systems (e.g. PROCESS TYPE and AGENCY, MOOD and POLARITY, or THEME and INFORMATION) and then extending these systems and their interactions in delicacy until relevant structural distinctions had been accounted for. Lexical insertion rules did arise as part of this process, for closed system items such as English do; but for the most part the formalization of lexical relations was positioned as a second step, dependent (in delicacy) on the general grammatical relations just reviewed.

One result of this is that a robust tradition of reasoning about lexical relations has not developed in SFL; there is nothing comparable to the decades of cryptogrammatical reasoning about grammatical relations in English and other languages. And uncertainty about how to motivate distinctions undermines our work on lexical relations whether we attempt to formalize these as delicate grammatical or discourse semantic oppositions. Work in corpus linguistics has shown us one possible path forward, as illustrated from Bednarek 2008 above; but corpora aren't anywhere near big enough at present to support the kind of fine-grained analysis we need. We know that we have to think relationally, and that the meaning of a word is its relationship with other words. But in the absence of corpus evidence, we don't know how to argue for one kind of relation or another, and for one kind of relation among relations or another. Clearly we need to move beyond a grammarian's vision of SFL; but how can we best prod our L1 to evolve?

As implicated in this paper, and the work inspired by Martin \& White 2005, the development of L2s addressing lexical relations will be a critical part of this process especially where the L2s are designed for text analysis (and especially where the text analysis is oriented to social problems arising in fields such as educational, clinical or forensic linguistics). For attitudinal relations, topology appears to be a more promising form of representation than typology - since there are so many relevant axes to consider and so many of them are clines. This reflects perhaps the sense in which lexical relations are a qualitatively different kind of phenomenon than grammatical ones. Lexis after all fine-tunes the meaning potential of a culture; there are many more lexical distinc- 
tions than grammatical ones. And lexis is also at a culture's cutting edge; words come and go as social practices ebb and flow. So the gaps, gluts and vagaries that currently frustrate our SFL L1 in fact afford our culture. We need to embrace this challenge, not hide from it - continuing to develop L2s that confound our L1. Otherwise most of the fine-gained meaning potential of a culture will remain untheorised. As functional linguists and semioticians, we need our L1 to do better than that.

\section{Appendix 1: Judgement systems}

Judgements of social esteem

\begin{tabular}{|l|l|l|}
\cline { 2 - 3 } \multicolumn{1}{c|}{} & \multicolumn{1}{c|}{ [positive] 'admire' } & \multicolumn{1}{c|}{ [negative] 'criticise' } \\
\hline $\begin{array}{l}\text { [normality] } \\
\text { (how special?) }\end{array}$ & $\begin{array}{l}\text { lucky, fortunate, charmed } \\
\text { normal, natural, familiar } \\
\text { in, fashionable, avant garde... }\end{array}$ & $\begin{array}{l}\text { unlucky, hapless, star-crossed } \\
\text { odd, peculiar, eccentric } \\
\text { dated, daggy, retrograde... }\end{array}$ \\
\hline $\begin{array}{l}\text { [capacity] } \\
\text { (how capable?) }\end{array}$ & $\begin{array}{l}\text { powerful, vigorous, robust } \\
\text { insightful, clever, gifted } \\
\text { balanced, together, sane... }\end{array}$ & $\begin{array}{l}\text { mild, weak, whimpy } \\
\text { slow, stupid, thick } \\
\text { flaky, neurotic, insane... }\end{array}$ \\
\hline $\begin{array}{l}\text { [tenacity] } \\
\text { (how dependable?) }\end{array}$ & $\begin{array}{l}\text { plucky, brave, heroic } \\
\text { reliable, dependable } \\
\text { tireless, persevering, resolute... }\end{array}$ & $\begin{array}{l}\text { unreliable, undependable } \\
\text { weak, distracted, dissolute.... }\end{array}$ \\
\hline
\end{tabular}

Judgements of social sanction

\begin{tabular}{|l|l|l|}
\cline { 2 - 3 } \multicolumn{1}{c|}{} & \multicolumn{1}{c|}{ [positive] 'praise' } & \multicolumn{1}{c|}{ [negative] 'condemn' } \\
\hline $\begin{array}{l}\text { [veracity] } \\
\text { (how honest?) }\end{array}$ & $\begin{array}{l}\text { truthful, honest, credible } \\
\text { frank, direct, candid } \\
\text { discrete, tactful... }\end{array}$ & $\begin{array}{l}\text { dishonest, deceitful, mendacious } \\
\text { deceptive, manipulative, devious } \\
\text { blunt, blabbermouth... }\end{array}$ \\
\hline $\begin{array}{l}\text { [propriety ] } \\
\text { (how far beyond reproach?) }\end{array}$ & $\begin{array}{l}\text { good, moral, ethical } \\
\text { law abiding, fair, just } \\
\text { sensitive, kind, caring... }\end{array}$ & $\begin{array}{l}\text { bad, immoral, evil } \\
\text { corrupt, unfair, unjust } \\
\text { insensitive, mean, cruel... }\end{array}$ \\
\hline
\end{tabular}

(C) J R Martin, 2017

\section{REFERENCES}

Almutairi, B A. A. (2013). Visualising patterns of appraisal in texts and corpora. Text \& Talk 33.4/5. $691-723$.

Bazell, C. E. (1966). In J. C. Catford \& M A K Halliday (Eds.) In Memory of J R Firth. London: Longman.

Bednarek, M. (2006). Evaluation in Media Discourse. Analysis of a Newspaper Corpus. London/New York: Continuum.

Bednarek, M. (2007). Polyphony in APPRAISAL; typological and topological perspectives. Linguistics and the Human Sciences 3.2. 107-136.

Bednarek, M. (2008). Emotion Talk across Corpora. London/New York: Palgrave Macmillan.

Bednarek, M. (2008). Semantic preference and semantic prosody re-examined. Corpus Linguistics and Linguistic Theory 4.2. 119-139.

Bernstein, B. (2000). Pedagogy, Symbolic Control and Identity: theory, research, critique. London: Taylor \& Francis. [Revised Edition].

de Souza, L. M. F. (2010). Interlingual re-instantiation: a model for a new and more comprehensive systemic functional perspective on translation. $\mathrm{PhD}$ Thesis. Universidade Federal de Santa Catarina, Brazil. 
Dreyfus, S. S. (2011). In Hood \& M Stenglin (Eds.) 2011 Semiotic Margins: meaning in multimodalities. London: Continuum.

Firth, J. R. (1957) A Synopsis of Linguistic Theory, 1930-1955. Studies in Linguistic Analysis (Special volume of the Philological Society). London: Blackwell. 1-31. [reprinted in F. R. Palmer 1968 [Ed.] Selected Papers of J R Firth, 1952 - 1959. London: Longman. 168 -205]

Halliday, M. A. K. (961). Categories of the theory of grammar. Word 17.3. 241-292.

Halliday, M. A. K. (1966). Lexis as a linguistic level. Bazell et al. 148-162.

Halliday, M. A. K. (1973). Explorations in the Functions of Language. London: Longman (Explorations in Language Study).

Halliday, M. A. K. \& J. R. Martin [Eds.] 1981 Readings in Systemic Linguistics. London: Batsford.

Halliday, M. A .K. \& C M I M Matthiessen (2014). An Introduction to Functional Grammar (4th edition). London: Arnold.

Hasan, R. (1987). The grammarian's dream: lexis as most delicate grammar. M A K Halliday \& R P Fawcett [Eds.] New Developments in Systemic Linguistics Vol. 1: theory and description. London: Pinter. 184-211. [reprinted in Ways of Saying: ways of meaning. 73-103].

Hjelmslev, L. (1947). Structural analysis of language. Studia Linguistica 1.1-3. 69-78.

Hunston, S. (2011). Corpus approaches to Evaluation.: phraseology and evaluative language. London: Routledge.

Knight, N. (2013). Evaluating experience in funny ways: how friends bond through conversational humour. Text \& Talk 33.4/5. 553-574.

Lamb, S. (1966). Epilegomena to a Theory of Language. Romance Philology. 531—573.

Lockwood, D. G. (1972). Introduction to Stratificational Linguistics. New York: Harcourt, Brace, Jovanovich.

Macken-Horarik, M. \& J.R. Martin (Eds.) 2003. Special issue of Text 23/2 on 'Appraisal'.

Malinowski, B. (1935). Coral Gardens and their Magic: a study of the methods of tilling the soil and of agricultural rites in the Trobriand Islands (Volume Two: The Language of Magic and Gardening). London: George Allen \& Unwin.

Martin, J R (1992). English Text: system and structure. Amsterdam: Benjamins.

Martin, J R (1997). ‘Analysing genre: functional parameters'. In: Christie, F. \& J. Martin (eds). Genres and Institutions: Social Processes in the Workplace and School. London: Cassell: 3-39.

Martin, J R (2000). Beyond exchange: appraisal systems in English. S Hunston \& G Thompson [eds.] Evaluation in Text: Authorial Stance and the Construction of Discourse. Oxford: OUP. $142-175$.

Martin, J R (2010a). Systemic Functional Linguistic Theory. Vol. 1 in the Collected Works of J R Martin (Wang Zhenhua Ed.). Shanghai: Shanghai Jiao Tong University Press.

Martin, J R (2010b). Semantic variation: modelling system, text and affiliation in social semiosis. M Bednarek \& J R Martin [Eds.] New Discourse on Language: functional perspectives on multimodality, identity and affiliation. London: Continuum. 1-34.

Martin, J R (2011). Multimodal semiotics: theoretical challenges. Dreyfus et al. 243-270.

Martin, J R (2013). Systemic Functional Grammar: a next step into the theory - axial relations. (Chinese translation and extensions by Wang Pin \& Zhu Yongsheng). Beijing: Higher Education Press.

Martin, J R \& C M I M Matthiessen (1991). Systemic typology and topology. F. Christie [Ed.] Literacy in Social Processes: papers from the inaugural Australian Systemic Linguistics Conference, held at Deakin University, January 1990. Darwin: Centre for Studies in Language in Education, Northern Territory University. 1991. 345-383. [Reprinted in Martin 2010. 167-215]

Martin, J R \& D Rose (2003). Working with Discourse: meaning beyond the. London: Continuum. [ $2^{\text {nd }}$ revised edition 2007] 
Martin, J R \& D Rose (2008). Genre Relations: mapping culture. London: Equinox.

Martin, J R \& P.R.R. White (2005). The Language of Evaluation: Appraisal in English. London/New York: Palgrave/Macmillan.

Martin, J R, Zappavigna M., Dwyer P. \& Cleirigh C. (2013). Users in uses of language: embodied identity in Youth Justice Conferencing. Text \& Talk 33.4/5. 467-496.

Maton, K. (2014). Knowledge and Knowers: Towards realist sociology of education. London: Routledge.

Matthiessen, C. M I M \& M A K Halliday (2009). Systemic functional grammar: a first step into the theory. Beijing: Higher Education Press.

Matthiessen, C. M I M \& C. Nesbitt (1996). On the idea of theory-neutral descriptions. In R Hasan, C. Cloran, \& D. Butt [Eds.] Functional descriptions: theory in practice. 38-84. Amsterdam: Benjamins.

McMurtie, R.J. (2013). Spatiogrammatics: a social semiotic perspective on moving bodies transforming the meaning potential of space. PhD Thesis: University of New South Wales.

Muller, J. (2007). On splitting hairs: hierarchy, knowledge and the school curriculum. In Christie \& Martin. 64-86.

Painter, C. (2003). Developing attitude: an ontogenetic perspective on APPRAISAL. Text 23.2. $183-210$.

Sinclair, J. McH (1966). Beginning the study of lexis. Bazell et al. 410 430.

Stenglin, M (2009). Space Odyssey: towards a social semiotic model of three-dimensional space. Visual Communication 8.1.39-64.

Stewart, D. (2010). Semantic Prosody: a critical evaluation. London: Routledge.

Tucker, G. H. (1998). The Lexicogrammar of Adjectives: a Systemic Functional approach to lexis. London: Cassell.

van Leeuwen, T. (2009). Parametric systems: the case of voice quality. C. Jewitt [Ed.] The Routledge Handbook of Multimodal Analysis Oxon/New York: Routledge. 68-77.

Whittaker, R. M. O’Donnell \& A. McCabe [Eds.] (2009) Advances in Language and Education. London: Continuum.

Wolfer, D. \& Harrison-Lever, B. (Illus.) (2005). Photographs in the Mud. Fremantle, W.A: Fremantle Arts Centre Press.

Zappavigna, M. (2011). Visualizing logogenesis: preserving the dynamics of meaning. Dreyfus et al. $211-228$.

Article history:

Received: 01 September 2016

Revised: 05 October 2016

Accepted: 29 October 2016

\section{For citation:}

Martin, J R (2017). The Discourse Semantics of Attitudinal Relations: Continuing the Study of Lexis. Russian Journal of Linguistics, 21 (1), $22-47$.

\section{Bio note}

$J R$ Martin is Professor of Department of Linguistics at the University of Sydney. Research Interests: Systemic Theory, Functional Grammar, Discourse Semantics, Register, Genre, Multimodality and Critical Discourse Analysis. Recent publications include The Language of Evaluation (with Peter White) Palgrave 2005; with David Rose, a second edition of Working with Discourse (Continuum 2007), a book on genre (Genre Relations, Equinox 2008) and an introduction to the genre-based literacy pedagogy of the 'Sydney School' (Learning to Write, Reading to Learn, Equinox 2012); with Clare Painter and Len Unsworth, a book on children's picture books (Reading Visual Narratives, Equinox 2013); and a book on system networks (Systemic Functional Grammar: a next step into 
the theory - axial relations, Higher Education Press, Beijing 2013). Eight volumes of his collected papers, edited by Wang Zhenhua, have been published in China (Shanghai Jiaotong University Press, 2010, 2012). A book reviewing his contributions to systemic functional linguistics has recently been published by Peking University Press: Zhu, Y S \& Z H Wang [Eds.] 2013 On J R Martin's Contribution to Systemic Functional Linguistics. Beijing: Peking University Press. Contact information: e-mail: james.martin@sydney.edu.au

УДК: 811.373 .17

DOІ: 10.22363/2312-9182-2017-21-1-22-47

\title{
ДИСКУРСИВНАЯ СЕМАНТИКА ПЕРЕДАЧИ ЭМОЦИОНАЛЬНОГО ОТНОШЕНИЯ: ПЕРСПЕКТИВЫ ИССЛЕДОВАНИЯ ЛЕКСИКИ
}

\author{
Дж. Р. Мартин \\ Центр прикладной лингвистики Мартина, \\ Шанхайский университет Джао Тонг \\ 200240, Шанхай, Kumaŭ, 800 Dongchuan Road \\ Университет Сиднея \\ NSW 2006, Австралия
}

\begin{abstract}
В данной статье рассматриваются некоторые аспекты проблемы категоризации оценочных отношений в английском языке как части описания оценки (Appraisal), основанной на системнофункциональной теории лингвистических исследований. В рамках данной традиции рассматриваются парадигматические и синтагматические подходы к лексике, а также развитие типологических и топологических представлений о системных отношениях. В статье высказывается отношение к возможности изучения оценки на основе корпусных данных, проведенного Беднарек (Bednarek 2008). Предлагается изучение лексики, выражающей негативные эмоции (грусть) и негативные реакции на поведение (например, смущение и стыд) на основе топологического подхода. Намечаются перспективы дальнейшего изучения лексики с применением основных положений системнофункциональной лингвистики.
\end{abstract}

Ключевые слова: оценка, системные отношения, эмоции, топологический подход, дискурсивная семантика

\section{История статьи:}

Дата поступления в редакцию: 01 сентября 2016

Дата принятия к печати: 29 октября 2016

Для цитирования:

Martin J R The discourse Semantics of Attitudinal Relations: Continuing the Study of Lexis // Вестник Российского университета дружбы народов. Серия: Лингвистика. 2017. Т. 21. № 1. C. $22-47$.

\section{Сведения об авторе:}

Дж. Р. Мартин, доктор филологических наук, профессор факультета лингвистики в Университете Сиднея (Австралия), ученый с мировым именем, внесший большой вклад в развитие системнофункциональной лингвистики. Среди его многочисленных публикаций: The Language of Evaluation (соавтор - Peter White) Palgrave, 2005; второе издание Working with Discourse (Continuum 2007), монография, посвященная жанрам - Genre Relations (Equinox 2008), Systemic Functional Grammar: a next step into the theory — axial relations, Higher Education Press, Beijing 2013) и многие другие. В Китае под редакцией Wang Zhenhua опубликовано 8 томов избранных трудов Дж. Мартина (Shanghai Jiaotong University Press, 2010, 2012), а также книга о его вкладе в системно-функциональную лингвистику: Zhu, Y S \& Z H Wang [Eds.] 2013 On J R Martin's Contribution to Systemic Functional Linguistics. Beijing: Peking University Press. Контактная информация: james.martin@sydney.edu.au 